\title{
LUMINESCENCE DATING OF YOUNG COASTAL DEPOSITS FROM NEW ZEALAND USING FELDSPAR
}

\author{
ANNI T. MADSEN ${ }^{1}$, JAN-PIETER BUYLAERT ${ }^{2,3}$ and ANDREW S. MURRAY ${ }^{2}$ \\ ${ }^{I}$ Department of Geography and Geology, University of Copenhagen \\ Øster Voldgade 10, DK-1350 Copenhagen K, Denmark \\ ${ }^{2}$ Nordic Laboratory for Luminescence Dating, Department of Earth Sciences, Aarhus University, \\ Risø National Laboratory for Sustainable Energy, Denmark \\ ${ }^{3}$ Radiation Research Division, Risø National Laboratory for Sustainable Energy, \\ Technical University of Denmark (DTU), Denmark
}

Received 30 April 2010

Accepted 28 March 2011

\begin{abstract}
A new measurement protocol has been tested on K-feldspars from Whanganui Inlet and Parengarenga Harbour, New Zealand. A Single Aliquot Regenerative (SAR) dose protocol, using two successive infrared (IR) stimulations (post-IR IR SAR protocol) is setup for these young $(<1000$ years) coastal sediments. Significant anomalous fading $\left(\mathrm{g}_{2 \text { days }}=7 \% /\right.$ decade) is observed using the conventional IR signal measured at $50^{\circ} \mathrm{C}$. In contrast, the fading rate of the IR signal measured at elevated temperature $\left(150^{\circ} \mathrm{C}\right.$ ) after the IR stimulation at $50^{\circ} \mathrm{C}$ (a post-IR IR signal) is not significant $\left(\mathrm{g}_{2 \text { days }} \leq 1 \% /\right.$ decade). Surprisingly low residual infrared stimulated luminescence (IRSL) signals were observed for a surface sample, suggesting that accurate ages as young as $\sim 50$ years can be obtained for these recent deposits. IRSL ages ranging between $48 \pm 6$ years and $1050 \pm 50$ years are obtained from six samples, indicating that sediment accumulation has occurred at the two sites during the last millennia, despite a falling trend in relative sea-level in Whanganui Inlet and a stable relative sealevel at Parengarenga Harbour.
\end{abstract}

Keywords: Luminescence dating, IRSL, K-feldspar, young sediments, New Zealand.

\section{INTRODUCTION}

Over the last few years luminescence dating has been more and more widely applied in studies of marine deposits and coastal change, and a large body of literature has become available describing the use of this dating technique on many types of coastal deposits, addressing a diverse range of local, regional and global issues. A comprehensive review by Jacobs (2008) compiles all these coastal studies and a review by Madsen and Murray (2009) summarizes the dating of young $(<1000$ years) coastal and aeolian sediments. So far, a limited number of

Corresponding author: A. T. Madsen e-mail: atm@geo.ku.dk studies have been published from coastal sites in New Zealand (Duller, 1996; Shulmeister et al. 1999; ReesJones et al. 2000; Nichol, 2002; Litchfield and Lian, 2004; Cooper and Kostro, 2006; Kennedy et al. 2007) and these have focused mainly on Pleistocene deposits (older than 10,000 years). Only Shulmeister and Kirk (1996) and Nichol et al. (2003) present chronologies on a millennial time-scale of Holocene (younger than 10,000 years) dune ridges. There has been almost no work on recent deposition of relevance to coastal management and pollution studies.

In some locations quartz has limited applicability because of low luminescence sensitivity (light output per unit dose). For instance, Preusser et al. (2006) concluded that the quartz from glacial sediments from the New 
Zealand Alps (Westland, South Island) was an unsuitable dosimeter for luminescence dating because of apparent low luminescence intensity and large sensitivity changes during the multiple measurement cycles in the Single Aliquot Regenerative (SAR) dose protocol. It is not known whether this problem prevents the use of quartz in the dating of very young/recent coastal New Zealand sediments.

Potassium-rich feldspar is an alternative dosimeter; it has the advantage that it is more likely to be sensitive, and so provides a measurable signal, but there are also disadvantages associated with this mineral. The solar resetting process occurs much more slowly for feldspar than for quartz (e.g. Godfrey-Smith et al. 1988). If the measurement of burial dose is to be accurate, then it is clearly very important that any trapped charge is completely reset prior to burial; the smaller the dose to be measured (as in very young sediments) the more important it is that this resetting process is complete (Madsen and Murray, 2009). Moreover, K-feldspar suffers from anomalous fading (Wintle, 1973); this expresses itself as an unexpected loss of luminescence signal with time, despite kinetic studies indicating that the signal should remain stable (Aitken, 1985). Reports of luminescence chronologies from New Zealand have shown that investigations based on either quartz or feldspar may run into difficulties (Duller, 1994a, 1994b; Pillans et al. 1996; Berger, et al. 2001; Almond et al. 2001, 2007; Preusser et al. 2006) due to anomalous fading in the case of feldspar and low luminescence sensitivity in the case of quartz.

This study aims to test the suitability of luminescence dating for establishing chronologies on a decadal to centurial time-scale on coastal New Zealand sediments. The use of both quartz and feldspar is explored. Most luminescence studies based on feldspar have employed infrared (IR) stimulation at $50^{\circ} \mathrm{C}$ (here abbreviated IR@50 $0^{\circ} \mathrm{C}$ ) and detection in the blue spectrum (e.g. Auclair et al. 2007; Wallinga et al. 2007; Buylaert et al. 2011; Davids et al. 2010). However Thomsen et al. (2008) concluded that the fading rate of these conventional IR signals is significantly higher than the fading rate of IR signals measured at an elevated stimulation temperature (e.g. $150^{\circ} \mathrm{C}$ ) after an IR@ $50^{\circ} \mathrm{C}$ (here called post-IR IR@ $150^{\circ} \mathrm{C}$ ). Buylaert et al. (2009) confirmed that this is also true in nature. In this study, we first test the sensitivity of quartz from 17 sites around the New Zealand coastline, and then test the application of a new post-IR IR Single Aliquot Regenerative (SAR) dose protocol on Krich feldspars from two sites. The ability of our protocol to recover a known dose given in the laboratory before heating is examined, and the laboratory fading rates are measured for both the IR@5 $50^{\circ} \mathrm{C}$ and post-IR IR@ $150^{\circ} \mathrm{C}$. The degree of bleaching is also examined using the most recently deposited material and the resulting post-IR IR ages.

\section{STUDY AREAS}

Preliminary investigations of the luminescence properties of quartz were undertaken on modern material taken from beach deposits at 17 different coastal locations in New Zealand (see Table 1 and Fig. 1). In addition, more detailed studies using K-feldspar were undertaken at one of these sites (Parengarenga) and at an additional site (Whanganui). The latter two sites are described in more detail below:

\section{Parengarenga Habour}

Parengarenga Harbour is a $\sim 63 \mathrm{~km}^{2}$ large meso-tidal estuary (tidal range $\sim 2 \mathrm{~m}$; Hayes, 1979) with generally less than ten metres water depth. The average volume of water exchanged during a tidal cycle is $25 \times 10^{6} \mathrm{~m}^{3}$ (Heath, 1975) and fresh water input amounts to $\sim 7 \mathrm{~m}^{3} \cdot \mathrm{s}^{-1}$ on average (Heath, 1976). The lagoon is located at the northernmost part of the Aupouri Peninsula in the far north of North Island (Fig. 1). The Northland area is generally accepted to be tectonically stable (Litchfield, pers. comm. 2010) and relative sea-level is thought to have been stable within $\pm 0.2 \mathrm{~m}$ during the last $\sim 6500$ years (Wellman, 1962; Gibb, 1986). Fluvial sediment input into Parengarenga Harbour is small; the largest fraction of the total sediment input is marine-derived (Pritchard et al. 1998). Inter-tidal sediments in Parengarenga Harbour are dominated by fine quartz-rich sands ( silica content $>95 \%$ ); inter-tidal mud is restricted to the very upper reaches of the estuary. The sand within the harbour is part of the Parengarenga Sand Facies defined by Schofield (1970). Three $5 \mathrm{~cm}$ thick inter-tidal samples (095502, 095503 and 095504) were taken from a shallow sediment core retrieved from Parengarenga Harbour (sample 095502 includes the modern surface). Sampling was not far from one of the relatively large tidal channels so the sediment may reflect point-bar sedimentation from migration of this channel rather than simple tidal flat deposition. A further sample (095501) was taken from an aeolian dune known to have formed since 1982; the evolution of the fore-dune has been surveyed in detail by sequential levelling (Parnell et al. 2003; pers. comm.).

\section{Whanganui Inlet}

Whanganui Inlet is a narrow estuary, $13 \mathrm{~km}$ long and up to $3 \mathrm{~km}$ wide $\left(\sim 40 \mathrm{~km}^{2}\right)$, located in the north-western part of South Island (Fig. 1). It has a semi-diurnal tide with a mean range of $3 \mathrm{~m}$ (Davidson, 1990) defining it as a meso-tidal estuary (Hayes, 1979). The average tidal prism is $20 \times 10^{6} \mathrm{~m}^{3}$ (Heath, 1975). Numerous small streams drain into the lagoon, resulting in an average freshwater input of $\sim 4 \mathrm{~m}^{3} \cdot \mathrm{s}^{-1}$ from the $216 \mathrm{~km}^{2}$ catchment (Heath, 1976). The dominant sediment source is thought to be these small streams (Armour and Kennedy, 2005). Relative sea-level has been decreasing slowly, due to local tectonic uplift during the Holocene (Litchfield, pers. 


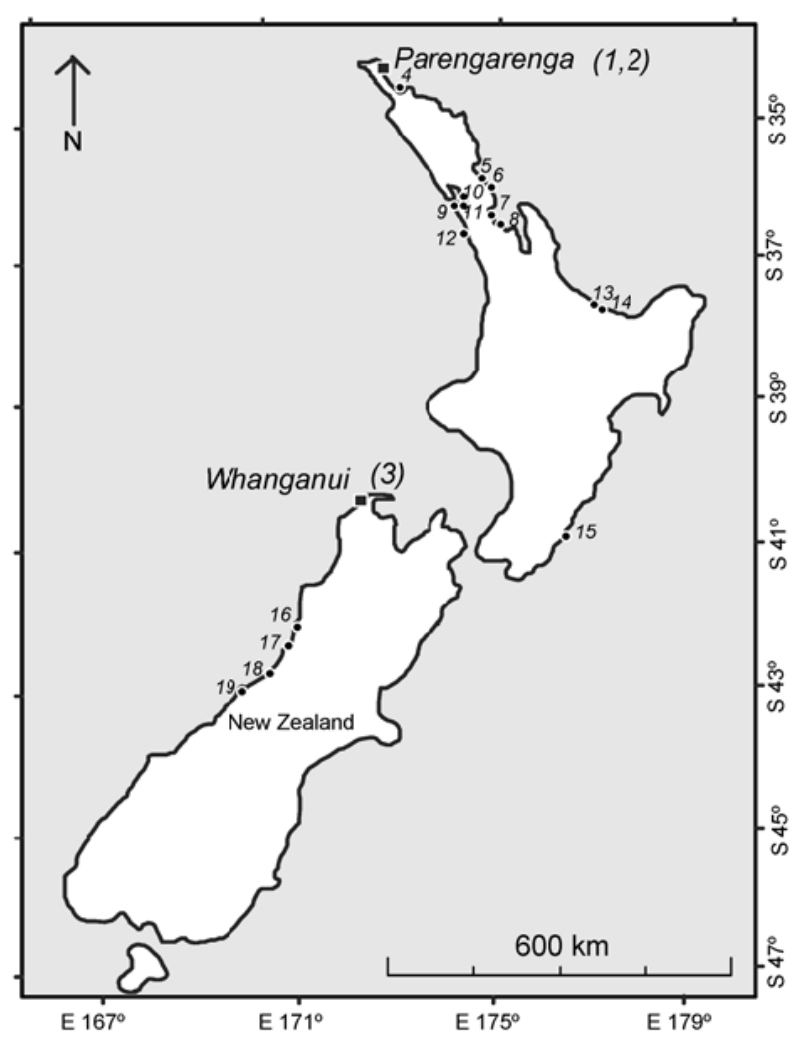

Fig. 1. Map displaying the nineteen sample locations in New Zealand; the main sites Parengarenga Harbour and Whanganui Inlet are highlighted.

comm. 2010). Whanganui inlet forms a structurallycontrolled estuary with most of the area made up of mudflats and sand flats exposed at low tide (Kennedy et al. 2008). The present surface morphology of Whanganui Inlet appears to be inherited from sedimentation that took place soon after the sea-level drop slowed up and stabilised; contemporary sedimentation on these tidal flats is therefore thought to be small (Kennedy et al. 2008). Armour and Kennedy (2005) argued that the tidal flats in Whanganui Inlet accreted rapidly after the postglacial marine flooding, based on radiocarbon ages of $\sim 7 \mathrm{ka}$ at a depth of only $1.8 \mathrm{~m}$, and so the tidal flats are thought to have reached modern elevations soon after initial sealevel flooding (Kennedy et al. 2008). Two ( $2 \mathrm{~cm}$ thick) samples (095509 and 095510) were recovered from a salt-marsh deposit fringing the lagoon at respectively $35 \mathrm{~cm}$ and $55 \mathrm{~cm}$ depth.

\section{METHODS}

\section{Sample preparation}

The 17 modern beach samples used to investigate the luminescence properties of quartz were etched with $\mathrm{HCl}$ $(10 \%), \mathrm{H}_{2} \mathrm{O}_{2}(10 \%)$, $\mathrm{HF}(40 \%)$, and finally $\mathrm{HCl}(10 \%)$ once more. In the case of samples taken for feldspar stud-
Table 1. GPS coordinates of sample locations. NI: North Island, SI: South Island.

\begin{tabular}{|c|c|c|}
\hline Sites & No & Coordinates \\
\hline Parengarenga & 1 Northland, NI (aeolian) & $\begin{array}{l}\text { S } 34^{\circ} 32^{\prime} 19.77^{\prime \prime} \\
\text { E } 172^{\circ} 59^{\prime} 23.12^{\prime \prime}\end{array}$ \\
\hline Parengarenga & 2 Northland, NI (inter-tidal) & $\begin{array}{l}\text { S } 34^{\circ} 31^{\prime} 42.12^{\prime \prime} \\
\text { E } 172^{\circ} 58^{\prime} 52.49^{\prime \prime}\end{array}$ \\
\hline Whanganui* & $3 \begin{array}{l}\text { Northeast coast, SI } \\
\text { (salt-marsh) }\end{array}$ & $\begin{array}{l}\text { S } 40^{\circ} 35^{\prime} 58.51^{\prime \prime} \\
\text { E } 172^{\circ} 34^{\prime} 50.56^{\prime \prime}\end{array}$ \\
\hline Eastern beach & 4 Northland, NI & $\begin{array}{l}\text { S } 34^{\circ} 53^{\prime} 05.57^{\prime \prime} \\
\text { E } 173^{\circ} 16^{\prime} 13.21^{\prime \prime}\end{array}$ \\
\hline Mangawhai & $\begin{array}{l}5 \text { east coast, north of } \\
\text { Auckland, } \mathrm{NI}\end{array}$ & $\begin{array}{l}\text { S } 36^{\circ} 05^{\prime} 32.88^{\prime \prime} \\
\text { E } 174^{\circ} 36^{\prime} 05.64^{\prime \prime}\end{array}$ \\
\hline Omaha Beach & $\begin{array}{l}\text { east coast, north of } \\
\text { Auckland, } \mathrm{NI}\end{array}$ & $\begin{array}{l}\text { S } 36^{\circ} 19^{\prime} 10.62^{\prime \prime} \\
\text { E } 174^{\circ} 46^{\prime} 45.75^{\prime \prime}\end{array}$ \\
\hline Orewa Beach & $\begin{array}{l}7 \text { east coast, north of } \\
\text { Auckland, } \mathrm{NI}\end{array}$ & $\begin{array}{l}\text { S } 36^{\circ} 35^{\prime} 52.15^{\prime \prime} \\
\text { E } 174^{\circ} 42^{\prime} 03.71^{\prime \prime}\end{array}$ \\
\hline Long Bay Beach & $\begin{array}{l}\text { east coast, north of } \\
\text { Auckland, } \mathrm{NI}\end{array}$ & $\begin{array}{l}\text { S } 36^{\circ} 41^{\prime} 48.17^{\prime \prime} \\
\text { E } 174^{\circ} 44^{\prime} 54.53^{\prime \prime}\end{array}$ \\
\hline Kaipara Harbour & $\begin{array}{l}\text { west coach, north of } \\
\text { Auckland, NI }\end{array}$ & $\begin{array}{l}\text { S } 36^{\circ} 23^{\prime} 13.27^{\prime \prime} \\
\text { E } 174^{\circ} 44^{\prime} 54.53^{\prime \prime}\end{array}$ \\
\hline Tapora & $\begin{array}{l}\text { west coach, north of } \\
\text { Auckland, } \mathrm{NI}\end{array}$ & $\begin{array}{l}\text { S } 36^{\circ} 22^{\prime} 57.26^{\prime \prime} \\
\text { E } 174^{\circ} 18^{\prime} 12.07^{\prime \prime}\end{array}$ \\
\hline Tauhoa & $\begin{array}{l}11 \text { west coach, north of } \\
\text { Auckland, NI }\end{array}$ & $\begin{array}{l}\text { S } 36^{\circ} 25^{\prime} 34.40^{\prime \prime} \\
\text { E } 174^{\circ} 26^{\prime} 27.16^{\prime \prime}\end{array}$ \\
\hline Piha Beach & $\begin{array}{l}12 \text { west coast, north of } \\
\text { Auckland, NI }\end{array}$ & $\begin{array}{l}\text { S } 36^{\circ} 57^{\prime} 25.95^{\prime \prime} \\
\text { E } 174^{\circ} 28^{\prime} 03.57^{\prime \prime}\end{array}$ \\
\hline Ohiwa Beach & 13 Bay of Plenty, NI & $\begin{array}{l}\text { S } 37^{\circ} 59^{\prime} 18.40^{\prime \prime} \\
\text { E } 177^{\circ} 09^{\prime} 18.96 "\end{array}$ \\
\hline Waiatahi estuary & 14 Bay of Plenty, NI & $\begin{array}{l}\text { S } 37^{\circ} 59^{\prime} 29.97^{\prime \prime} \\
\text { E } 177^{\circ} 11^{\prime} 57.46^{\prime \prime}\end{array}$ \\
\hline Castle Point Inlet & 15 Southeast coast, NI & $\begin{array}{l}\text { S } 40^{\circ} 54^{\prime} 16.60^{\prime \prime} \\
\text { E } 176^{\circ} 13^{\prime} 41.42^{\prime \prime}\end{array}$ \\
\hline Taramakau & 16 west coast, SI & $\begin{array}{l}\text { S } 42^{\circ} 33^{\prime} 02.17^{\prime \prime} \\
\text { E } 171^{\circ} 08^{\prime} 12.36^{\prime \prime}\end{array}$ \\
\hline Hokitika & 17 west coast, SI & $\begin{array}{l}\text { S } 42^{\circ} 43^{\prime} 17.55^{\prime \prime} \\
\text { E } 171^{\circ} 57^{\prime} 12.37^{\prime \prime}\end{array}$ \\
\hline Okarito Lagoon & 18 west coast, SI & $\begin{array}{l}\text { S } 43^{\circ} 13^{\prime} 12.00^{\prime \prime} \\
\text { E } 170^{\circ} 11^{\prime} 13.98^{\prime \prime}\end{array}$ \\
\hline Gillespies & 19 west coast, SI & $\begin{array}{l}\text { S } 43^{\circ} 13^{\prime} 21.80^{\prime \prime} \\
\text { E } 169^{\circ} 49^{\prime} 15.92^{\prime \prime}\end{array}$ \\
\hline
\end{tabular}

*note that $Q$ was not investigated at this site

ies, the cores were opened under subdued orange light and split into two halves; one half for equivalent dose $\left(D_{e}\right)$ measurements (see later) and another half for dose rate estimation (see later). Samples for $D_{e}$ measurements were first wet-sieved to isolate material in the 106-212 $\mu \mathrm{m}$ and the $80-300 \mu \mathrm{m}$ grain-size range for Parengarenga and Whanganui, respectively (the larger interval at Whanganui was because of insufficient material). These fractions were then treated with $\mathrm{HCl}(10 \%)$ and $\mathrm{H}_{2} \mathrm{O}_{2}(10 \%)$ to remove carbonates and organic material. A K-rich feldspar extract (density $<2.58 \mathrm{~g} \cdot \mathrm{cm}^{-3}$ ) was then separated using heavy liquids and etched for $40 \mathrm{~min}$ with diluted HF $(10 \%)$ to remove the outer alpha-irradiated layer from the grains. After etching, any contaminating fluorides were dissolved using $\mathrm{HCl}(10 \%)$. 
All luminescence measurements were made with a Risø TL/OSL reader equipped with a ${ }^{90} \mathrm{Sr} /{ }^{90} \mathrm{Y}$ beta-source $\left(0.044 \pm 0.001 \mathrm{~Gy} \cdot \mathrm{s}^{-1}\right)$ and light sources, consisting of blue diodes emitting at $470 \mathrm{~nm}$ and IR diodes emitting at $875 \mathrm{~nm}$ (Bøtter-Jensen et al. 2003). Luminescence was detected in the UV through a U340 glass filter for quartz measurements and in the blue-violet through a Schott BG39/Corning 7-59 glass filter combination for feldspar measurements.

For dose rate determination, samples were dried to laboratory humidity to determine field water content, ignited at $450^{\circ} \mathrm{C}$ for 24 hours, and subsequently homogenised by grinding to a grain-size of $<200 \mu \mathrm{m}$. The homogenised samples were mixed with wax, cast in a fixed cup-shaped geometry, and stored for three weeks to allow the establishment of secular equilibrium between ${ }^{222} \mathrm{Rn}$ and ${ }^{226} \mathrm{Ra}$. Saturated water content was measured on a sub-sample of the unground material.

\section{Preliminary tests on quartz}

Large $(\sim 8 \mathrm{~mm})$ aliquots of quartz grains were prepared using silicone oil to adhere the grains to a $10 \mathrm{~mm}$ diameter stainless steel discs. The purity of the quartz extracts was confirmed by the absence of any IRSL sensitivity. The blue-light stimulated luminescence signals were measured in the usual manner (preheat at $260^{\circ} \mathrm{C}$ for $10 \mathrm{~s}$ and $40 \mathrm{~s}$ stimulation at $125^{\circ} \mathrm{C}$ with $90 \%$ blue LED power). These preliminary investigations mostly involved measurement of laboratory test doses $(\sim 18 \mathrm{~Gy})$, but the quartz sample from Parengarenga (site number 2) was also used in a dose recovery test, because this sample showed the greatest sensitivity (see section 4).

\section{Equivalent dose measurement on feldspars}

For feldspar investigations, small $(\sim 2 \mathrm{~mm})$ aliquots containing a few hundred grains were mounted on stainless steel discs with silicone oil. The post-IR IR SAR protocol used in this study (Table 2) is based on the protocol proposed by Buylaert et al. (2009). For the first

Table 2. Post-IR IR SAR protocol for K-feldspars (modified after Buylaert et al. 2009).

\begin{tabular}{lll}
\hline Step & Treatment & Observe \\
\hline 1 & Give dose, $\mathrm{D}_{\mathrm{i}}$ & \\
\hline 2 & Preheat $\left(180^{\circ} \mathrm{C}\right.$ for $\left.10 \mathrm{~s}\right)$ & \\
\hline 3 & Optically stimulate with IR diodes for $500 \mathrm{~s} @ 50^{\circ} \mathrm{C}$ & \\
\hline 4 & $\begin{array}{l}\text { Optically stimulate with IR diodes for } 100 \mathrm{~s} @ 150^{\circ} \mathrm{C} \\
\left(30 \mathrm{~s} \text { pause after heating to } 150^{\circ} \mathrm{C}\right)\end{array}$ \\
\hline 5 & Give test dose, $\mathrm{Lt}$ \\
\hline 6 & Heat to $160^{\circ} \mathrm{C}(<$ preheat temperature, step 2) & \\
\hline 7 & Optically stimulate with IR diodes for $500 \mathrm{~s} @ 50^{\circ} \mathrm{C}$ & \\
\hline 8 & $\begin{array}{l}\text { Optically stimulate with IR diodes for } 100 \mathrm{~s} @ 150^{\circ} \mathrm{C} \\
\left.\text { (30 s pause after heating to } 150^{\circ} \mathrm{C}\right)\end{array}$ \\
\hline 9 & $\begin{array}{l}\text { Optically bleach with IR diodes for } 100 \mathrm{~s} @ 200^{\circ} \mathrm{C} \\
\text { (> preheat temperature) }\end{array}$ \\
\hline 10 & Return to 1 & \\
\hline
\end{tabular}

SAR cycle, which measures the natural dose originating from the radiation field present in the natural environment, no laboratory dose was administered. The following SAR cycles measure doses given by a beta source in the laboratory (step 1). The samples were then preheated for $10 \mathrm{~s}$ at $180^{\circ} \mathrm{C}$ (step 2), followed by an IR stimulation at $50^{\circ} \mathrm{C}$ for $500 \mathrm{~s}$ (step 3) and a second IR stimulation for $100 \mathrm{~s}$, when the sample was held at $150^{\circ} \mathrm{C}$ (step 4); here the luminescence $\left(\mathrm{L}_{\mathrm{i}}\right)$ is measured. Correction for sensitivity changes throughout the measurement cycles is done by application of a constant test dose (step 5) as part of the SAR procedure (Murray and Wintle, 2000). The test dose $(\sim 1.1$ Gy) was measured in a similar manner to that used for the natural 'burial' and regenerated doses. The samples are first heated to $160^{\circ} \mathrm{C}$ (step 6) and then stimulated by IR diodes for $500 \mathrm{~s}$ at $50^{\circ} \mathrm{C}$ (step 7) followed by an IR stimulation for $100 \mathrm{~s}$ at $150^{\circ} \mathrm{C}$ (step 8) where the test dose response $\left(\mathrm{T}_{\mathrm{i}}\right)$ is measured. After every SAR cycle, the samples are optically bleached using IR diodes for $100 \mathrm{~s}$ at $200^{\circ} \mathrm{C}$ (step 9) to reduce recuperation (Murray and Wintle, 2003). The preheat/cut-heat, stimulation and illumination temperatures are lower than those used by Buylaert et al. (2009) because of the expected young age of the sediment and the necessity to reduce thermal transfer as much as possible. In practice, $\mathrm{L}_{\mathrm{i}}$ and $\mathrm{T}_{\mathrm{i}}$ are calculated using both the IR@50 ${ }^{\circ} \mathrm{C}$ and pIRIR@150 15 signals, to allowing a comparison of the behaviour of the two signals $\left(\mathrm{L}_{\mathrm{i}}\right.$ and $\mathrm{T}_{\mathrm{i}}$ of the IR@50 $0^{\circ} \mathrm{C}$ signal are measured in steps 3 and 7, respectively). The initial $10 \mathrm{~s}$ minus a background derived from the last $50 \mathrm{~s}$ was used for calculations with the IR@ $50^{\circ} \mathrm{C}$ signal. For the pIRIR@ $150^{\circ} \mathrm{C}$ signal the net signal was calculated from the first $1.85 \mathrm{~s}$ minus a background from the last $8.9 \mathrm{~s}$.

Fig. 2a shows examples of the natural IR@50 $50^{\circ} \mathrm{de}-$ cay curves from five of the samples and Fig. 2b shows the immediately following pIRIR@ $150^{\circ} \mathrm{C}$ decay curves. Inset are typical SAR growth curves (corrected IRSL $\left(\mathrm{L}_{\mathrm{i}} / \mathrm{T}_{\mathrm{i}}\right)$ is plotted against laboratory dose; filled circles) for sample 095503. The open circle (recycling point) indicates a repeated measurement and shows that the SAR protocol successfully corrects for sensitivity changes. The recuperation point (triangle at a dose of zero Gy) lies close to, but a little above the origin for the pIRIR@ $150^{\circ} \mathrm{C}$ signal. The laboratory dose equivalent to the burial dose is found by interpolation of the corrected natural signals onto the appropriate SAR growth curve and is termed the equivalent dose, $D_{e}(G y)$. In all cases, to determine $D_{e}$, we assume that the growth curve passes through the origin.

\section{Dose rate}

Radionuclide concentrations (in $\mathrm{Bq} \cdot \mathrm{kg}^{-1}$ ) were measured using high-resolution gamma spectrometry (Murray et al. 1987). These radionuclide concentrations were then converted to dry infinite matrix dose rates using the conversion factors listed by Olley et al. (1996) before the contribution from the cosmic ray dose rate was added 
(Prescott and Hutton, 1994). The contribution from internal beta activity from ${ }^{40} \mathrm{~K}$ was taken into account based on an assumed effective potassium content of $12.5 \pm 0.5 \%$ (following Huntley and Baril, 1997). A small contribution to the beta dose rate from ${ }^{87} \mathrm{Rb}$ is calculated assuming a $\mathrm{Rb}$ content of $400 \pm 100 \mathrm{ppm}$ (Huntley and Hancock, 2001). Estimates of water content were used to reduce the dose rates, using the equations given by Aitken (1985). An average value between the measured field water content and the saturated water content was used in this dose rate correction for the supra-tidal Whanganui samples and the aeolian sample from Parengarenga. The inter-tidal
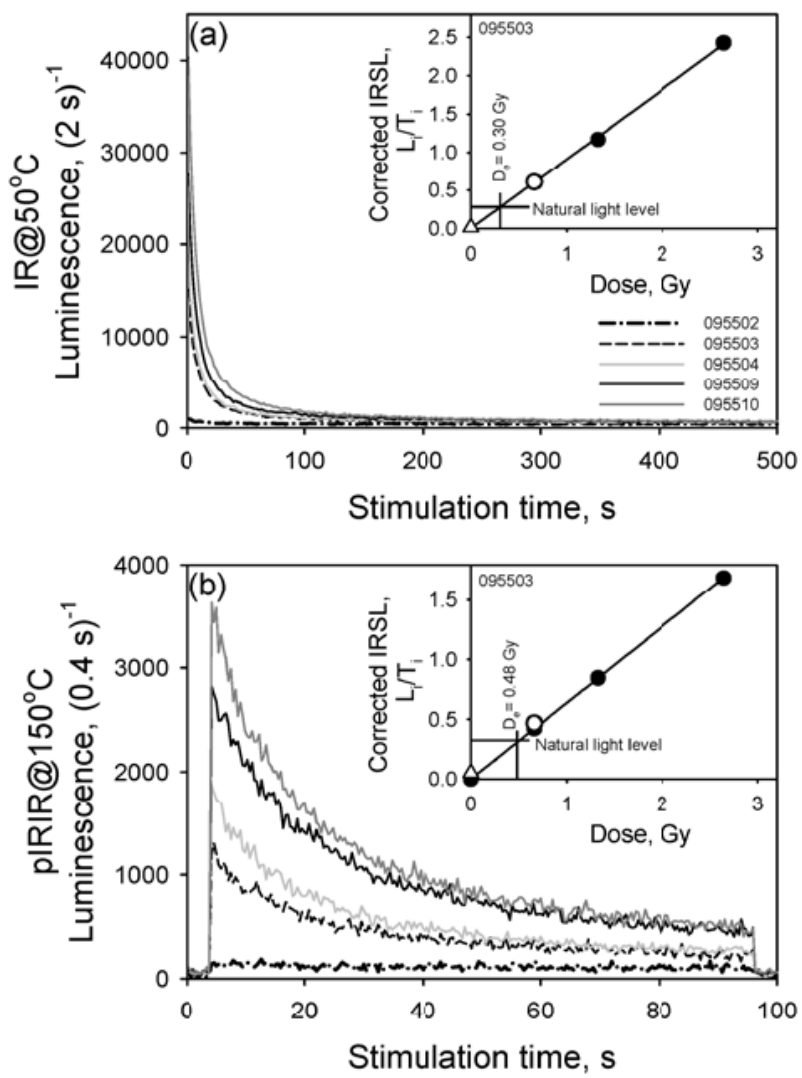

Fig. 2. a) Stimulation decay curves of the natural IR@50 ${ }^{\circ} \mathrm{C}$ signal, and b) stimulation decay curves of the following pIRIR@150 15 signal from samples 095502, 095503, 095504, 095509 and 095510. SAR growth curves for sample 095503 are inset.
Parengarenga samples were assumed to always have been saturated because frequent tidal inundations probably maintain the sediment in a near saturated state. The dose rate model by Madsen et al. (2005) was applied to take the temporal variability of sample depth into account; this is inevitable when dating young near-surface sediments in accreting environments. The contribution from cosmic ray dose rate decreases as the sediment is buried deeper and deeper but the gamma dose rate increases as the contribution from overlying sediments increases. Radionuclide concentrations $\left({ }^{226} \mathrm{Ra},{ }^{232} \mathrm{Th}\right.$ and $\left.{ }^{40} \mathrm{~K}\right)$ are presented in Table 3, together with water content and total dose rates.

\section{LUMINESCENCE CHARACTERISTICS}

\section{Sensitivity of quartz}

Fig. 3 shows two representative examples of decay curves from the preliminary quartz tests; the least sensitive (Piha beach, number 12) and the most sensitive (Parengarenga, number 2). In neither case there is a dominant fast component and the material is, in general, very insensitive (only between 800-3000 counts for the first $0.16 \mathrm{~s}$, when a test dose of $\sim 18 \mathrm{~Gy}$ is applied; we wish to measure 10-100 mGy natural doses). In addition to low sensitivity, we observed significant sensitivity changes of the quartz from all sites except Parengarenga. A dose recovery test was therefore only undertaken on the quartz from Parengarenga (data not shown). The resulting dose recovery ratios gave a satisfactory mean value of $1.06 \pm 0.05(\mathrm{n}=45)$, but the standard deviation was $>30 \%$. This suggests that Parengarenga quartz could probably be used to date old sediment, but not material in the age range of interest here.

\section{Dose recovery test on feldspars}

A dose recovery test was undertaken for sample 095502,095503 and 095510 in order to check that our SAR protocol is able to accurately measure doses given in the laboratory without prior heating. First, the aliquots were optically bleached twice for $40 \mathrm{~s}$ (at room temperature) separated by a pause of $10,000 \mathrm{~s}$, using IR diodes. They were then given a known dose of 5.5 Gy. All aliquots were then measured using the post-IR IR SAR

Table 3. Sample depth, water content, radionuclide concentrations and total dose rates.

\begin{tabular}{|c|c|c|c|c|c|c|c|}
\hline $\begin{array}{c}\text { Sample } \\
\text { code }\end{array}$ & $\begin{array}{l}\text { Lab. } \\
\text { code }\end{array}$ & $\begin{array}{l}\text { Depth } \\
\text { (cm) }\end{array}$ & $\begin{array}{l}\text { W.c. } \\
(\%)\end{array}$ & $\begin{array}{c}{ }^{226} \mathrm{Ra} \\
\left(\mathrm{Bq} \cdot \mathrm{kg}^{-1}\right)\end{array}$ & $\begin{array}{c}{ }^{232} \mathrm{Th} \\
\left(\mathrm{Bq} \cdot \mathrm{kg}^{-1}\right)\end{array}$ & $\begin{array}{c}{ }^{40} \mathrm{~K} \\
\left(\mathrm{~Bq} \cdot \mathrm{kg}^{-1}\right)\end{array}$ & $\begin{array}{c}\text { Dose rate } \\
\left(G_{y} \cdot \mathrm{ka}^{-1}\right)\end{array}$ \\
\hline WHEL1 & 095509 & 35 & 276 & $29.1 \pm 3.9$ & $44.7 \pm 0.4$ & $560 \pm 60$ & $1.80 \pm 0.08$ \\
\hline WHEL2 & 095510 & 55 & 108 & $30.2 \pm 2.6$ & $45.9 \pm 2.7$ & $660 \pm 40$ & $2.55 \pm 0.08$ \\
\hline PAR-aeolian & 095501 & 65 & 19 & $4.0 \pm 0.5$ & $0.7 \pm 0.5$ & $84 \pm 5$ & $1.26 \pm 0.05$ \\
\hline PAR2-0 & 095502 & 1 & 34 & $\mathrm{~N} / \mathrm{A}$ & $\mathrm{N} / \mathrm{A}$ & $\mathrm{N} / \mathrm{A}$ & $1.13 \pm 0.06$ \\
\hline PAR2-45 & 095503 & 45 & 34 & $4.0 \pm 0.5$ & $0.7 \pm 0.5$ & $84 \pm 5$ & $1.13 \pm 0.05$ \\
\hline PAR2-75 & 095504 & 75 & 34 & $\mathrm{~N} / \mathrm{A}$ & $\mathrm{N} / \mathrm{A}$ & $\mathrm{N} / \mathrm{A}$ & $1.11 \pm 0.05$ \\
\hline
\end{tabular}

N/A - not available 
protocol given in Table 2, but with varying preheat temperature $\left(160-280^{\circ} \mathrm{C}\right.$ in step 2) and a fixed cut-heat of $160^{\circ} \mathrm{C}$ (step 6). The dose recovery temperature plateaus (IR@50 $5{ }^{\circ} \mathrm{C}$ in Fig. 4a and pIRIR@ $150^{\circ} \mathrm{C}$ in Fig. 4c) suggests that the dose measurement is insensitive to preheat temperature (measured to given dose ratios are within $10 \%$ of unity); recycling ratios are close to unity at all preheat temperatures $\left(160-280^{\circ} \mathrm{C}\right)$, and the recuperation only increases slightly with increased preheat temperature, never exceeding 0.2 Gy (Figs. 4b and 4d). However, the dose could not be recovered properly in sample 095510 (the recovered dose is about $50 \%$ higher than the given dose) using the pIRIR@ $150^{\circ} \mathrm{C}$; the reason for this is unknown.

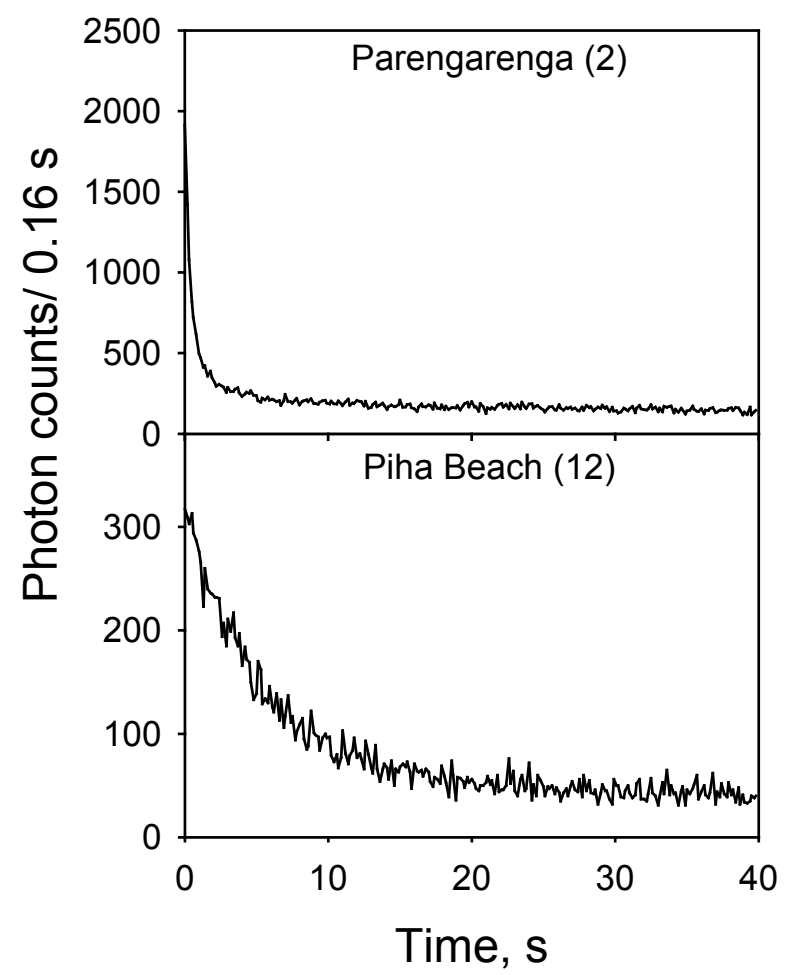

Fig. 3. Two examples of stimulation decay curves of New Zealand quartz. The most sensitive signal (from Parengarenga) is displayed in the upper part of the diagram and the least sensitive signal (from Piha beach) is displayed in the lower part of the diagram.

\section{Anomalous fading test on feldspars}

In the laboratory, anomalous fading was monitored by measuring the small decrease in IRSL intensity with storage time after the irradiation. For most K-feldspars the signal loss decreases linearly with the logarithm of time and this fading rate is usually quantified by the gvalue (Aitken, 1985, Appendix F); this is a measure of the fading rate as a percentage of signal lost during a storage period of one decade of time (the storage period expressed in decades relative to the laboratory irradiation period). The approach by Auclair et al. (2003) was used to measure the anomalous fading in our samples on aliquots that were previously used for $D_{e}$ determination; measurement of repeated $L_{i} / T_{i}$ cycles were carried out with different time delays inserted after the preheating step. Time delays varied from $\sim 0.2 \mathrm{~h}$ for prompt (immediate) measurements, up to $\sim 25 \mathrm{~h}$ for the longest delay measurements. The g-values for both the IR@50 $50^{\circ} \mathrm{C}$ and pIRIR@ $150^{\circ} \mathrm{C}$ signals were then calculated using the equation by Huntley and Lamothe (2001) and normalised to a measurement delay time $\left(t_{c}\right)$ of 2 days after irradiation; this analysis assumes that the fading of the signals is logarithmic. Examples of fading rates are presented in Fig. 5 and g-values are summarized in Table 4.

Fading rates for the IR@50 $50^{\circ} \mathrm{C}$ signal vary between $4.1 \pm 0.5$ and $9.3 \pm 0.3 \%$ /decade, with an average of $7.1 \pm 0.3 \% /$ decade $(n=15)$. Despite these significant fading rates for the low temperature IR signal the pIRIR@150 15 signal does not appear to show significant fading, with values ranging between $-1.7 \pm 1.3$ and $1.0 \pm 1.1$ $\% /$ decade, with an average of $0.2 \pm 0.2 \% /$ decade $(n=15)$. Thus we are only justified in applying a fading correction to the IR@ $50^{\circ} \mathrm{C}$ data. It should also be noted that the range in g-values is much larger for sample 095510 than for the other samples (see Table 4).

\section{CHRONOLOGY}

\section{Equivalent doses}

Equivalent dose $\left(D_{e}\right)$ measurements were undertaken on 2-24 aliquots (using both IR@ $50^{\circ} \mathrm{C}$ and pIRIR@ $150^{\circ} \mathrm{C}$ signals) resulting in dose distributions from which a mean and standard error were derived. Fig. 6 presents four examples of such dose distributions based on the conventional IR@50 $5{ }^{\circ} \mathrm{C}$ signal and Fig. 7 presents corresponding dose distributions based on the pIRIR@150 15 signal; the obvious outliers are discarded

Table 4. Results from the fading tests (g-values).

\begin{tabular}{|c|c|c|c|c|c|c|c|c|c|c|}
\hline \multirow[t]{2}{*}{ Sample } & \multicolumn{2}{|c|}{095510} & \multicolumn{2}{|c|}{095501} & \multicolumn{2}{|c|}{095502} & \multicolumn{2}{|c|}{095503} & \multicolumn{2}{|c|}{095504} \\
\hline & IR@50 $0^{\circ} \mathrm{C}$ & pIRIR@150 & IR@50 ${ }^{\circ} \mathrm{C}$ & plRIR@150 $\mathrm{C}$ & IR@50 ${ }^{\circ} \mathrm{C}$ & pIRIR@150 ${ }^{\circ} \mathrm{C}$ & IR@50C & plRIR@150 $\mathrm{C}$ & IR@50 $\mathrm{C}$ & pIRIR@150 \\
\hline Fading rates & $9.3 \pm 0.3$ & $-1.7 \pm 1.3$ & $4.9 \pm 0.3$ & $0.6 \pm 0.4$ & $6.8 \pm 0.3$ & $-0.2 \pm 0.8$ & $6.2 \pm 0.4$ & $1.0 \pm 1.4$ & $7.2 \pm 0.4$ & $0.3 \pm 1.0$ \\
\hline g-value & $7.6 \pm 0.7$ & $1.0 \pm 2.3$ & $6.3 \pm 0.5$ & $-0.8 \pm 1.0$ & $7.7 \pm 0.3$ & $0.2 \pm 1.1$ & $8.1 \pm 0.4$ & $0.7 \pm 1.1$ & $7.9 \pm 0.4$ & $0.3 \pm 0.8$ \\
\hline (\%/decade) & $4.1 \pm 0.5$ & $0.5 \pm 2.4$ & $7.9 \pm 0.3$ & $1.0 \pm 1.1$ & $7.3 \pm 0.3$ & $-0.2 \pm 0.8$ & $7.0 \pm 0.2$ & $-0.1 \pm 0.9$ & $7.9 \pm 0.2$ & $0.6 \pm 0.9$ \\
\hline Average & $7.0 \pm 1.5$ & $-0.1 \pm 0.8$ & $6.3 \pm 0.9$ & $0.3 \pm 0.5$ & $7.3 \pm 0.3$ & $-0.1 \pm 0.1$ & $7.1 \pm 0.5$ & $0.6 \pm 0.3$ & $7.7 \pm 0.2$ & $0.4 \pm 0.1$ \\
\hline
\end{tabular}


for the age calculation. It is interesting to note that the dose distributions from pIRIR@150 $\mathrm{C}$ measurements are wider than the dose distributions from IR@ $950^{\circ} \mathrm{C}$ measurements.

\section{Age correction}

We can now apply the age correction model of Huntley and Lamothe (2001) to the ages based on the apparently fading IR@50 $50^{\circ} \mathrm{C}$ signals. The average $\mathrm{D}_{\mathrm{e}}$ value and the average fading rate per sample were used (unfortunately there was insufficient material to determine the fading rate for sample 095509 , and so the fading rate determined using the other sample (095510) from the same site was employed). These revised ages are also summarized in Table 5 together with the fading corrected equivalent doses. On average, the IR@50 $50^{\circ} \mathrm{C}$ ages become about $60 \%$ older. Fig. 8 shows the $\mathrm{D}_{\mathrm{e}}$ estimates based on the IR@50 $50^{\circ} \mathrm{C}$ signal plotted against those from the

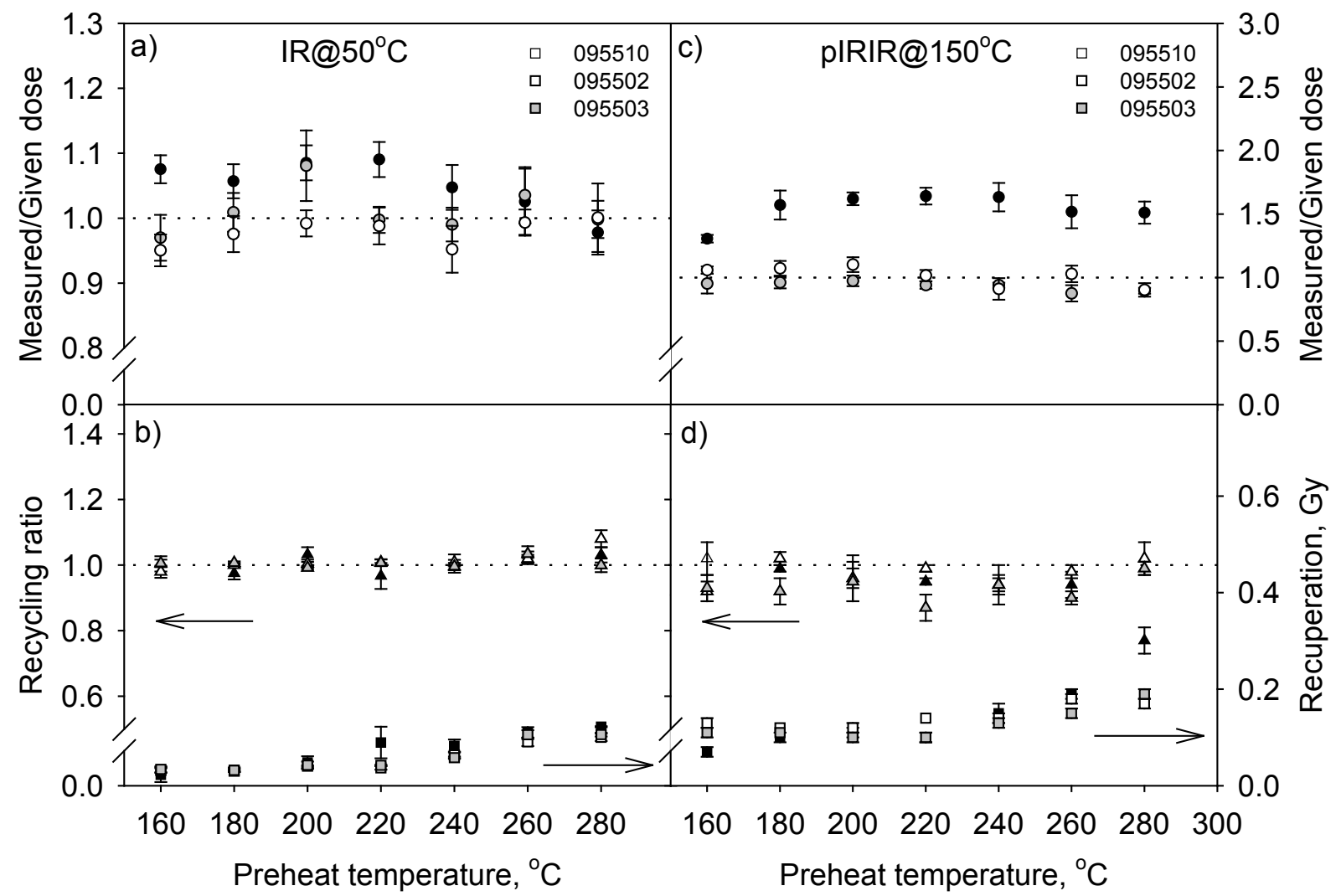

Fig. 4. Dose recovery test, using preheat temperatures ranging between $160-280^{\circ} \mathrm{C}$, for samples of sample 095510 (black), 095502 (white) and 095503 (grey). Aliquots were first optically bleached twice for $40 \mathrm{~s}$ (at room temperature) separated by a pause of $10 \mathrm{ks}$, using IR diodes, then given a dose of $5.5 \mathrm{~Gy}$. All aliquots were then measured using the post-IR IR SAR protocol, with a fixed cut-heat of $160^{\circ} \mathrm{C}$. a) Dose recovery ratio as a function of preheat temperature, when using the IR@50 ${ }^{\circ} \mathrm{C}$ signal. b) Variation of recuperation (squares) and recycling ratio (triangles) with temperature based on the IR@50 ${ }^{\circ} \mathrm{C}$ signal. c) Dose recovery ratio as a function of preheat temperature, when using the pIRIR@150 $\mathrm{C}$ signal. b) Variation of recuperation (squares) and recycling ratio (triangles) with temperature based on the pIRIR@150 $\mathrm{C}$ signal.

Table 5. Sample depth, ' $n$ ', equivalent doses based on respectively the IR@50 $\mathrm{C}$ signal and the pIRIR@150 $\mathrm{C}$ signal and the corresponding IRSL ages. Fading correction was undertaken for IRSL ages based on the IR@50 ${ }^{\circ} \mathrm{C}$ signal.

\begin{tabular}{|c|c|c|c|c|c|c|c|c|c|}
\hline \multirow[b]{2}{*}{$\begin{array}{c}\text { Sample } \\
\text { code }\end{array}$} & \multirow[b]{2}{*}{$\begin{array}{l}\text { Lab. } \\
\text { code }\end{array}$} & \multirow[b]{2}{*}{$\begin{array}{l}\text { Depth } \\
\text { (cm) }\end{array}$} & \multirow[b]{2}{*}{$\mathrm{n}$} & \multicolumn{4}{|c|}{$\mathrm{IR} @ 50^{\circ} \mathrm{C}$} & \multicolumn{2}{|c|}{ pIRIR@150C } \\
\hline & & & & $\begin{array}{l}D_{e} \\
(G y)\end{array}$ & $\begin{array}{l}\text { Fading correc- } \\
\text { ted } D_{e},(G y)\end{array}$ & $\begin{array}{l}\text { IRSL age } \\
\text { (a) }\end{array}$ & $\begin{array}{l}\text { Fading correct- } \\
\text { ed IRSL age (a) }\end{array}$ & $\begin{array}{l}D_{e} \\
(G y)\end{array}$ & $\begin{array}{l}\text { IRSL age } \\
\text { (a) }\end{array}$ \\
\hline WHEL1 & 095509 & 35 & 2 & $1.10 \pm 0.07$ & $2.03 \pm 0.16$ & $610 \pm 50$ & $1130 \pm 100$ & $1.45 \pm 0.03$ & $800 \pm 40$ \\
\hline WHEL2 & 095510 & 55 & 23 & $2.41 \pm 0.07$ & $4.44 \pm 1.09$ & $930 \pm 40$ & $1740 \pm 430$ & $2.66 \pm 0.06$ & $1050 \pm 50$ \\
\hline PAR-aeolian & 095501 & 65 & 17 & $0.022 \pm 0.002$ & $0.033 \pm 0.004$ & $18 \pm 2$ & $27 \pm 3$ & $0.08 \pm 0.02$ & $60 \pm 16$ \\
\hline PAR2-0 & 095502 & 1 & 23 & $0.033 \pm 0.002$ & $0.054 \pm 0.004$ & $29 \pm 2$ & $48 \pm 4$ & $0.05 \pm 0.01$ & $48 \pm 6$ \\
\hline PAR2-45 & 095503 & 45 & 23 & $0.298 \pm 0.015$ & $0.53 \pm 0.05$ & $265 \pm 15$ & $470 \pm 50$ & $0.46 \pm 0.02$ & $400 \pm 25$ \\
\hline PAR2-75 & 095504 & 75 & 15 & $0.300 \pm 0.004$ & $0.56 \pm 0.02$ & $270 \pm 15$ & $510 \pm 30$ & $0.40 \pm 0.01$ & $355 \pm 20$ \\
\hline
\end{tabular}



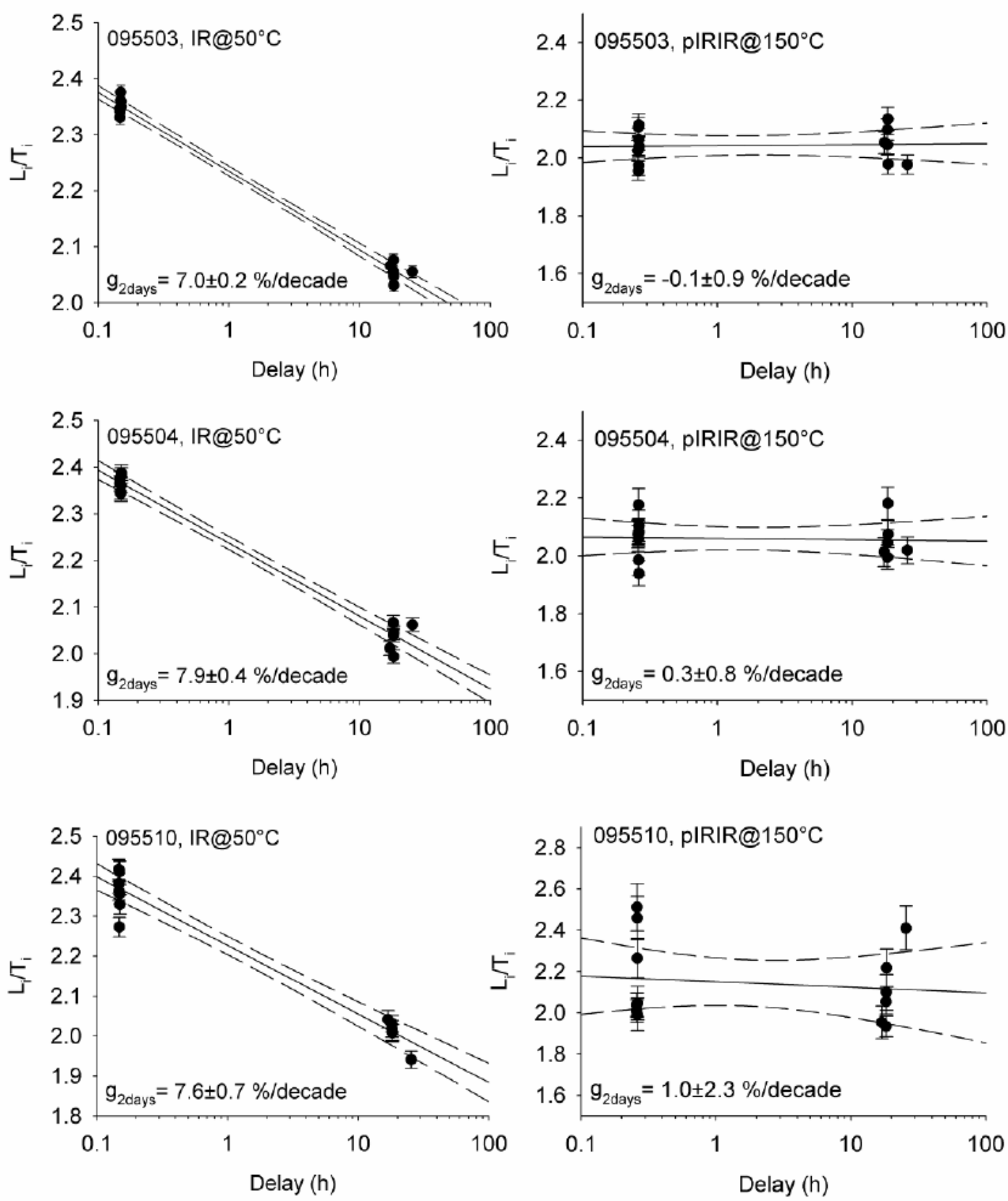

Fig. 5. Anomalous fading plots for samples 095503, 095504, 095510. Left plots show the IR@50 $\mathrm{C}$ signal, right plots the pIRIR@150 $\mathrm{C}$ signal. The dashed lines represent a $95 \%$ confidence interval.

pIRIR@ $150^{\circ} \mathrm{C}$ signal; open circles are without fading correction and filled circles have been corrected for fading. In general, the uncorrected IR@50 $50^{\circ} \mathrm{C}$ results are closer to the pIRIR@ $150^{\circ} \mathrm{C}$, but the deviation of the corrected and uncorrected IR@50 $50^{\circ} \mathrm{C}$ from the 1:1 line is only marked for sample 095510 . This is the sample giving the largest spread in g-values and the poorest dose recovery (see section 4.2). Given the good reproducibility of the uncorrected $D_{e}$ values, it seems most likely that the larger g-values are in error. It is also interesting that the data (Fig. 8) are consistent with a line passing through the origin, indicating that any residual dose at the time of burial (or any thermal transfer initiated during measurement) is similar for the two signals. The pIRIR@ $150^{\circ} \mathrm{C}$ results are preferred, because they do not show any fading in the laboratory, and the resulting ages range between $48 \pm 6$ and $1050 \pm 50$ years.

\section{DISCUSSION}

Although the new post-IR IR SAR protocol has performed satisfactorily in a dose recovery test (except for 

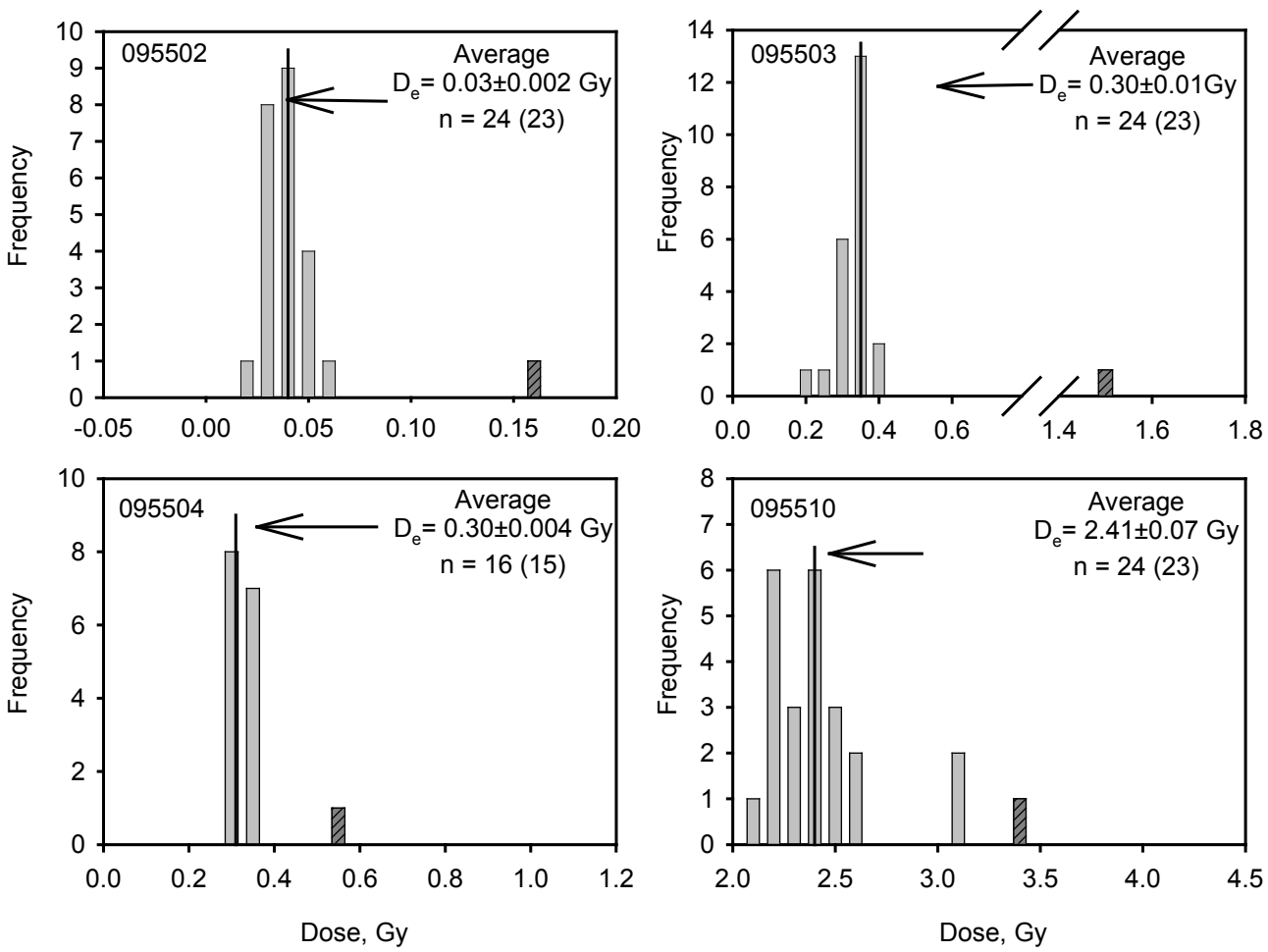

Fig. 6. Dose distributions of samples $095502,095503,095504$ and 095510 . The IR@ $00^{\circ} \mathrm{C}$ signal is used for these plots. ' $n$ ' is the number of observations. The number in brackets is the number of aliquots included in the calculation of the mean; obvious outliers are displayed as dark grey dashed bars.
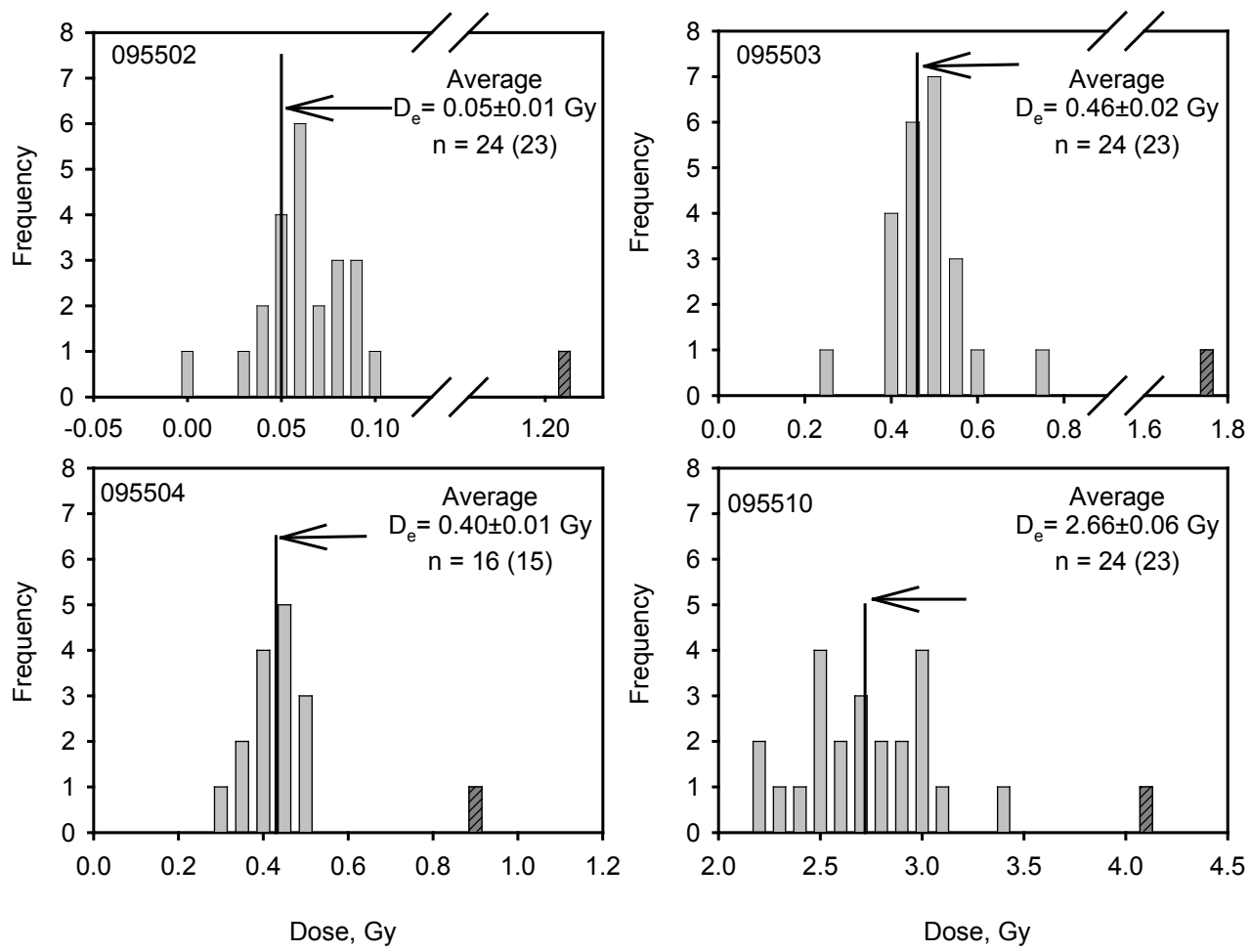

Fig. 7. Dose distributions of sample $095502,095503,095504$ and 095510 . The pIRIR@ $150^{\circ} \mathrm{C}$ signal is used for these plots. ' $n$ ' is the number of observations. The number in brackets is the number of aliquots included in the calculation of the mean; obvious outliers are displayed as dark grey dashed bars. 


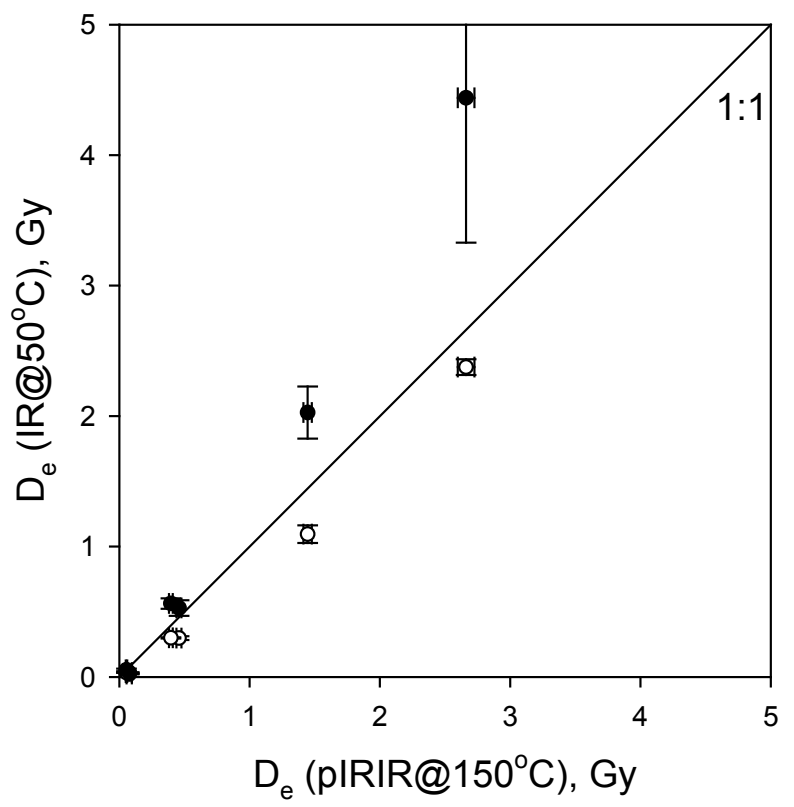

Fig. 8. Equivalent dose estimates based on the IR@50 $\mathrm{C}$ signal plotted against the equivalent dose estimates based on the pIRIR@150 ${ }^{\circ} \mathrm{C}$ signal; open circles are without fading correction and filled circles are fading corrected.

sample 095510) this is not a complete test of the reliability of the SAR protocol because in nature the environmental dose rate is about $10^{9}$ less than in the laboratory. The most comprehensive test is to date known-age samples. Unfortunately, independent age information is scarce in this study. The result from the aeolian sample (095501) from Parengarenga is our best attempt to date a known-age deposit. The coastal dune from which the material was sampled is known to have formed since 1982 based on sequential levelling surveys (Parnell et al. 2003; pers. comm.) and the age is estimated to lie between modern and 27 years old, compared to an IRSL age of $60 \pm 16$ years.

It is known that quartz in such shallow coastal environments is very likely to be well-bleached (Madsen and Murray, 2009) but the solar resetting process is slower for feldspar than for quartz (e.g. Godfrey-Smith et al., 1988). Thus we cannot be certain that these feldspar samples have been fully reset, and that residual doses at burial can be neglected. One way of evaluating minimum residual doses is to consider the modern surface sample (095502) and the very recent aeolian material (095501; discussed above) from Parengarenga. The total dose (IR@50 $\mathrm{C}$ and pIRIR@150 ${ }^{\circ} \mathrm{C}$ ) in the modern surface (095502) from Parengarenga was in the range 30-50 mGy (Table 5). This sample included the top $5 \mathrm{~cm}$ of the inter-tidal sediment core; if the sedimentation rate is assumed to be about $2 \mathrm{~mm} \cdot \mathrm{a}^{-1}$, then this means that the average age of the $5 \mathrm{~cm}$ slice is 12.5 years, corresponding to a dose of $\sim 14 \mathrm{mGy}$. This suggests that residual doses are $\sim 20 \mathrm{mGy}$ for IR@50 $\mathrm{C}$ signals and $\sim 35 \mathrm{mGy}$ for pIRIR@ $150^{\circ} \mathrm{C}$ signals. The very recent aeolian material (095501) is known to have a finite age of 0-27 years (see above). Using the mid-point of this range as our age estimate gives an expected dose of $\sim 20 \mathrm{mGy}$. The observed total doses were $22 \mathrm{mGy}$ based on IR@50 ${ }^{\circ} \mathrm{C}$ signals (implying a residual of only $\sim 3 \mathrm{mGy}$ ) and 80 mGy based on pIRIR@ $150^{\circ} \mathrm{C}$ signals (residual of $\sim 60 \mathrm{mGy}$ ). It is reasonable to assume that the aeolian sand will have received much more light exposure than the upper layers of marine sediment. This suggests that in both cases the signals are reset as completely as possible, but that there is some irreducible minimum dose that cannot be readily bleached, $\sim 10 \mathrm{mGy}$ for the IR@50 $50^{\circ} \mathrm{C}$ signals and $\sim 50$ mGy for pIRIR@ $150^{\circ} \mathrm{C}$. It seems likely that these values reflect thermal transfer from light insensitive traps, rather than actual incomplete bleaching of light sensitive traps.

This research was undertaken to determine whether it is possible to reconstruct the response to a stable or falling sea-level at coastal sites in New Zealand. As a result, this study was directed primarily towards investigating the suitability of these New Zealand deposits for dating very recent deposition events. Because of this, there is only a limited number of luminescence ages, but nevertheless some preliminary interpretation can be made. About half a metre of material has accumulated on the salt-marsh in Whanganui Inlet during the last millennium; a preliminary sedimentation rate for this salt-marsh is in the range $0.5-0.8 \mathrm{~mm} \cdot \mathrm{a}^{-1}$ (when averaging between $0-55 \mathrm{~cm}$ or $35-55 \mathrm{~cm}$ depth). Thus accumulation has continued in supra-tidal areas in Whanganui Inlet during the last $\sim 1000$ years, despite the slowly decreasing relative sea-level resulting from a local tectonic uplift rate of $0-1 \mathrm{~mm} \cdot \mathrm{a}^{-1}$ (Litchfield, pers. comm. 2010). The core retrieved from Parengarenga Harbour gives a preliminary sedimentation rate of $\sim 2 \mathrm{~mm} \cdot \mathrm{a}^{-1}$ (when averaging between $0-75 \mathrm{~cm}$ ). This estimate seems relatively high, given that sea-level in this area has been almost stable since the mid-Holocene ( $\sim 6500$ years ago; Gibb, 1986). However, sampling was undertaken in near proximity to one of the large tidal channels, and so this sedimentation rate may relate more to channel migration rather than simple tidal flat deposition. In the lateral displacement of tidal channels large amounts of sediment are able to accumulate almost instantaneously as point-bar sedimentation, giving rise to a sediment packet with apparent constant ages with depth (Fruergaard et al. 2011). This is presumably the reason why almost identical ages are observed at $45 \mathrm{~cm}$ and $75 \mathrm{~cm}$ depth in the Parengarenga core.

\section{CONCLUSIONS}

This study has tested a new protocol for K-feldspar luminescence dating on young coastal sediments from New Zealand, and IRSL ages ranging between 48-1050 years have been obtained. One of the major challenges associated with IRSL dating of K-feldspar is the signal 
loss due to anomalous fading, which necessitates the use of age correction models. Our new protocol appears to sample a new and apparently more stable luminescence signal by measuring IRSL at elevated temperature $\left(150^{\circ} \mathrm{C}\right)$ immediately after a long IR@50 $50^{\circ} \mathrm{C}$ stimulation (the pIRIR@ $150^{\circ} \mathrm{C}$ signal). We are unable to detect significant laboratory fading of this pIRIR@ $150^{\circ} \mathrm{C}$ signal (g-values range between $-1.7 \pm 1.3$ and $1.0 \pm 1.1 \% /$ decade) whereas the conventional IR@ $50^{\circ} \mathrm{C}$ signal gives fading rates

$\sim 7 \% /$ decade. The youngest ages observed here $(48 \pm 6$ years for inter-tidal sediment and $60 \pm 16$ years for aeolian sediment) were only slightly older than the likely depositional ages of these deposits, indicating considerable potential for the dating of recent coastal deposits in New Zealand.

\section{ACKNOWLEDGEMENTS}

Financial support from the Nordic Centre of Excellence programme of the Joint Committee of Nordic Natural Science Research Councils and Geocenter Danmark (grant no. 603-00003) is gratefully acknowledged. An 'EliteForsk' travelling-grant from the Danish Agency for Science, Technology and Innovation has moreover paid for the field-work in New Zealand. The 2009 Parengarenga survey team, consisting of Paul, Roger, Quentin, Scott, Kevin and Peter, are greatly thanked for their assistance in the field. Brigida O. Figueira is thanked for kindly providing samples from Whanganui Inlet. Our colleagues at Risø National Laboratory, Kristina Thomsen, Christina Ankjærgaard and Reza Sohbati are thanked for sharing their knowledge about feldspar luminescence. Sébastien Huot is thanked for making the Excel macros for g-value calculation and fading correction available to us.

\section{REFERENCES}

Aitken MJ, 1985. Thermoluminescence dating. London, Academic Press Inc: $359 \mathrm{pp}$

Almond PC, Moar NT and Lian OB, 2001. Reinterpretation of the glacial chronology of South Westland, New Zealand. New Zealand Journal of Geology and Geophysics 44(1): 1-15, DOI 10.1080/00288306.2001.9514917.

Almond PC, Shanhun FL, Rieser U and Shulmeister J, 2007. An OSL radiocarbon and tehpra isochron-based chronology for Birdlings flat loess at Ahuriri Quarry, Banks Peninsula, Canterbury, New Zealand. Quaternary Geochronology 2(1-4): 4-8, DOI 10.1016/j.quageo.2006.06.002.

Armour RK and Kennedy DM, 2005. Comparative palynomorph signals of vegetation change preserved in an adjacent peat swamp and estuary in North-West Nelson, New Zealand. New Zealand Journal of Botany 43(2): 451-465, DOI 10.1080/0028825X.2005.9512967.

Auclair M, Lamothe M and Huot S, 2003. Measurement of anomalous fading for feldspar IRSL using SAR. Radiation Measurements 37(4-5): 487-492, DOI 10.1016/S1350-4487(03)00018-0.

Auclair M, Lamothe M, Lagroix F and Banerjee SK, 2007. Luminescence investigations of loess and tephra from Halfway House section, Central Alaska. Quaternary Geochronology 2(1-4): 34-38, DOI 10.1016/j.quageo.2006.05.009.
Berger GW, Almond PC and Pillans BJ, 2001. Luminescence dating and glacial stratigraphy in Westland, New Zealand. New Zealand Journal of Geology and Geophysics 44(1): 25-35, DOI 10.1080/00288306.2001.9514919.

Bøtter-Jensen L, Andersen CE, Duller GAT and Murray AS, 2003. Developments in radiation, stimulation and observation facilities in luminescence measurements. Radiation Measurements 37(4-5): 535-541, DOI 10.1016/S1350-4487(03)00020-9.

Buylaert JP, Murray AS, Thomsen KJ and Jain M, 2009. Testing the potential of an elevated temperature IRSL signal from K-feldspar. Radiation Measurements 44(5-6): 560-565, DOI 10.1016/j.radmeas.2009.02.007.

Buylaert JP, Huot S, Murray AS and Van den Haute P, 2011. Infrared stimulated luminescence dating of an Eemian (MIS 5e) site in Denmark using K-feldspar. Boreas 40(1): 46-56, DOI 10.1111/j.1502-3885.2010.00156.x.

Cooper AF and Kostro F, 2006. A tectonically uplifted marine shoreline deposit, Knights Point, Westland, New Zealand. New Zealand Journal of Geology and Geophysics 49(2): 203-216, DOI 10.1080/00288306.2006.9515160.

Davids F, Duller GAT and Roberts HM, 2010. Testing the use of feldspars for optical dating of hurricane overwash deposits. Quaternary Geochronology 5(2-3): $125-130, \quad$ DOI 10.1016/j.quageo.2009.03.001.

Davidson RJ, 1990. A report on the ecology of Whanganui Inlet, northwest Nelson. Occasional Publication, vol. 2. Department of Conservation, Nelson/Marlborough Conservancy, New Zealand.

Duller GAT, 1994a. Luminescence dating of sediments using single aliquots: New procedures. Quaternary Science Reviews 13(2): 149-156, DOI 10.1016/0277-3791(94)90041-8.

Duller GAT, 1994b. Luminescence dating using feldspars: a test case from southern North Island, New Zealand. Quaternary Science Reviews 13(5-7): 423-427, DOI 10.1016/0277-3791(94)90053-1.

Duller GAT, 1996. The age of the Koputaroa dunes, southwest North Island, New Zealand. Palaeogeography, Palaeoclimatology, Palaeoecology 121(1-2): 105-114, DOI 10.1016/00310182(96)00053-3.

Fruergaard M, Andersen TJ, Madsen AT, Christensen L, Nielsen LH, Johannessen PN, Murray AS and Pejrup M, 2011. Punctuated sedimentation resulting from channel migration in a shallow sanddominated micro-tidal lagoon, Northern Wadden Sea, Denmark. Marine Geology 280(1-4): 91-104, DOI 10.1016/j.margeo.2010.12.003.

Gibb JG, 1986. A New Zealand regional Holocene eustatic sea-level curve and its application to determination of vertical tectonic movements. Royal Society New Zealand Bulletin 14: 377-395.

Godfrey-Smith DL, Huntley DJ and Chen WH, 1988. Optically dating studies of quartz and feldspar sediment extracts. Quaternary Science Reviews 7(3-4): 373-380, DOI 10.1016/0277-3791(88)90032-

Hayes MO, 1979. Barrier island morphology as a function of tidal influence and wave regime. In: Leathermann SP, ed., Barrier Islands. Academic Press, New York: 1-27.

Heath RA, 1975. Stability of some New Zealand coastal inlets. New Zealand Journal of Marine and Freshwater Research 9(4): 449457, DOI 10.1080/00288330.1975.9515580.

Heath RA, 1976. Broad classification of New Zealand inlets with emphasis on residence times. New Zealand Journal of Marine and Freshwater Research 10(3): 429-444, DOI 10.1080/00288330.1976.9515628.

Huntley DJ and Baril MR, 1997. The K content of the K-feldspars being measured in optical dating or in thermoluminescence dating. Ancient TL 15: 11-13.

Huntley DJ and Hancock RGV, 2001. The Rb contents of the Kfeldspar grains being measured in optical dating. Ancient TL 19: 43-46.

Huntley DJ and Lamothe M, 2001. Ubiquity of anomalous fading in Kfeldspars and the measurement and correction for it in optical dating. Canadian Journal of Earth Science 38(7): 1093-1106, DOI 10.1139/e01-013. 
Jacobs Z, 2008. Luminescence chronologies for coastal and marine sediments. Boreas 37(4): 508-535, DOI $10.1111 / \mathrm{j} .1502-$ 3885.2008.00054.x.

Kennedy DM, Tannock KL, Crozier MJ and Rieser U, 2007. Boulders of MIS 5 age deposited by a tsunami on the coast of Otago, New Zealand. Sedimentary Geology 200(3-4): 222-231, DOI 10.1016/j.sedgeo.2007.01.005.

Kennedy DM, Paulik R and Millar M, 2008. Infill of a structurally controlled estuary: An example from southern Whanganui Inlet, New Zealand. New Zealand Geographer 64(1): 20-33, DOI 10.1111/j.1745-7939.2008.00124.x.

Litchfield NJ and Lian OB, 2004. Luminescence age estimates of Pleistocene marine terrace and alluvial fan sediments associated with tectonic activity along coastal Otago, New Zealand. New Zealand Journal of Geology and Geophysics 47(1): 29-37, DOI 10.1080/00288306.2004.9515035.

Litchfield N, pers. comm. 2010. GNS Science, Lower Hutt, Wellington, New Zealand.

Madsen AT, Murray AS, Andersen TJ, Pejrup M and Breuning-Madsen $\mathrm{H}, 2005$. Optically stimulated luminescence dating of young estuarine sediments: a comparison with ${ }^{210} \mathrm{~Pb}$ and ${ }^{137} \mathrm{Cs}$ dating. Marine Geology 214(1-3): 251-268, DOI 10.1016/j.margeo.2004.10.034.

Madsen AT and Murray AS, 2009. Optically stimulated luminescence dating of young sediments: a review. Geomorphology 109(1-2): 316, DOI 10.1016/j.geomorph.2008.08.020.

Murray AS, Marten R, Johnston A and Martin P, 1987. Analysis for naturally occuring radionuclides at environmental concentrations by gammaspectrometry. Journal of Radioanalytical and Nuclear Chemistry 115(2): 263-288, DOI 10.1007/BF02037443.

Murray AS and Wintle AG, 2000. Luminescence dating of quartz using an improved single-aliquot Regenerative-dose protocol. Radiation Measurements 32(1): 57-73, DOI 10.1016/S1350-4487(99)00253$\mathrm{X}$.

Murray AS and Wintle AG, 2003. The single aliquot regenerative dose protocol: potential for improvements in reliability. Radiation Measurements 37(4-5): 377-381, DOI 10.1016/S13504487(03)00053-2.

Nichol SL, 2002. Morphology, stratigraphy and origin of last interglacial beach ridges at Bream Bay, New Zealand. Journal of Coastal Research 18: 149-159.

Nichol SL, Lian OB and Carter CH, 2003. Sheet-gravel evidence for a late Holocene tsunami run-up on beach dunes, Great Barrier Island, New Zealand. Sedimentary Geology 155(1-2): 129-145, DOI 10.1016/S0037-0738(02)00191-4.

Olley J, Murray AS and Roberts RG, 1996. The effects of disequilibria in the uranium and thorium decay chains on burial dose rates in fluvial sediments. Quaternary Science Reviews 15(7): 751-760, DOI 10.1016/0277-3791(96)00026-1.

Parnell KE, Hosking PL and Nichol SL, 2003 (pers. comm.). Parengarenga Monitoring Programme. Summary of surveys August 1998 - February 2003 and Summary of all surveys 1982-
2003. Unpublished Report prepared for ACI New Zealand Glass Manufacturers Ltd.

Pillans B, Kohn BP, Berger G, Froggatt P, Duller G, Alloway B and Hesse P, 1996. Multi-method dating comparison for midPleistocene Rangitawa tephra, New Zealand. Quaternary Science Reviews 15(7): 641-653, DOI 10.1016/0277-3791(96)00035-2.

Prescott JR and Hutton JT, 1994. Cosmic ray contributions to dose rates for luminescence and ESR dating: large depths and long-term variations. Radiation Measurements 23(2-3): 497-500, DOI 10.1016/1350-4487(94)90086-8.

Preusser F, Ramseyer K and Schlüchter C, 2006. Characterisation of low OSL intensity quartz from the New Zealand Alps. Radiation Measurements 41(7-8): 10.1016/j.radmeas.2006.04.019.

Pritchard J, Osbourne P, Parnell K and Nichol SL, 1998. Sediment transport trends, Parengarenga Harbour. In: Forer PC, Lumsden J and Perry PJ, eds. Proceedings of the $18^{\text {th }}$ New Zealand Geographical Society Conference, vol. 18. Dunidin, New Zealand.

Schofield JC, 1970. Coastal sands of Northland and Auckland. New Zealand Journal of Geology and Geophysics 13: 767-823.

Rees-Jones J, Rink WJ, Norris RJ and Litchfield NJ, 2000. Optical luminescence dating of uplifted marine terraces along the Akatore Fault near Dunedin, South Island, New Zealand. New Zealand Journal of Geology and Geophysics 43(3): 419-424, DOI 10.1080/00288306.2000.9514898.

Shulmeister J and Kirk RM, 1996. Holocene history and a thermoluminescence based chronology of coastal dune ridges near Leithfield, North Canterbury, New Zealand. New Zealand Journal of Geology and Geophysics 39(1): 25-32, DOI 10.1080/00288306.1996.9514692.

Shulmeister J, Soons JM, Berger GW, Harper M, Holt S, Moar N and Carter JA, 1999. Environmental and sea-level changes on Banks Peninsula (Canterbury, New Zealand) through three glaciation interglaciation cycles. Palaeogeography, Palaeoclimatology, Palaeoecology 152(1-2): 101-127, DOI 10.1016/S00310182(99)00035-8.

Thomsen KJ, Murray AS, Jain M and Bøtter-Jensen L, 2008. Laboratory fading rates of various luminescence signals from feldspar-rich sediment extracts. Radiation Measurements 43(9-10): 1474-1486, DOI 10.1016/j.radmeas.2008.06.002.

Wallinga J, Bos AJJ, Dorenbos P, Murray AS and Schokker J, 2007. A test case for anomalous fading correction in IRSL dating. Quaternary Geochronology 2(1-4): 216-221, DOI 10.1016/j.quageo.2006.05.014.

Wellman HW, 1962. Holocene of the North Island of New Zealand: a coastal reconnaissance. Transactions of the Royal Society of New Zealand Geology 1(5): 29-99.

Wintle AG, 1973. Anomalous fading of thermoluminescence in mineral samples. Nature 245(5421): 143-144, DOI 10.1038/245143a0. 